\title{
Isolation, Screening and Characterization of Cellulase Producing Bacterial Isolates from Municipal Solid Wastes and Rice Straw Wastes
}

Prabesh Khatiwada, Jahed Ahmed, Mehadi Hasan Sohag, Kamrul Islam and Abul Kalam Azad*

Department of Genetic Engineering and Biotechnology, Shahjalal University of Science and Technology, Sylhet-3114, Bangladesh

\begin{abstract}
Cellulolytic bacteria were isolated and screened from municipal solid wastes and rice straw wastes using Carboxy Methyl Cellulose (CMC) agar medium as a selective medium. Production of clear zones by the bacterial isolates on $\mathrm{CMC}$ agar medium supplemented with $1 \% \mathrm{CMC}$ was considered as indicative of extracellular cellulase activity. The size of transparent zone diameter was considered as proportional to the level of cellulase production. These bacterial isolates were identified as Bacillus sp., Pseudomonas sp. and Serratia sp. based on morphological, cultural and biochemical characteristics. A basal medium containing $\mathrm{CMC}, \mathrm{KH}_{2} \mathrm{PO}_{4}, \mathrm{~K}_{2} \mathrm{HPO}_{4}, \mathrm{MgSO}_{4},\left(\mathrm{NH}_{4}\right)_{2} \mathrm{SO}_{4}, \mathrm{CaCl}_{2}$ and $\mathrm{FeSO}_{4}$ at pH 7.0 was used for cellulase production. The assay of cellulase in term of CMCase was performed by measuring the release of reducing sugar. Different physicochemical parameters were optimized for cellulase production at shake flask fermentation. Time course study revealed that maximum level of cellulase was produced by Bacillus and Serratia isolates after $24 \mathrm{~h}$ of cultivation and by Pseudomonas isolates after $42 \mathrm{~h}$ of cultivation. Optimum level of cellulase was produced by Pseudomonas and Bacillus isolates at $37^{\circ} \mathrm{C}$, and that by Serratia isolate was at $35^{\circ} \mathrm{C}$. Optimum $\mathrm{pH}$ for cellulase production by these bacterial isolates was 7.0 . Optimum temperature and $\mathrm{pH}$ for the activity of cellulase from these isolates were $40^{\circ} \mathrm{C}$ and 7.0 , respectively. The cellulase from these isolates was found almost stable up to $55^{\circ} \mathrm{C}$ and at $\mathrm{pH} 7.0$ for $1 \mathrm{~h}$. The crude cellulase could liberate reducing sugar from filter paper through hydrolysis. Results showed that bacterial isolates produced significant level of cellulase with cellulose degrading capability.
\end{abstract}

Keywords: Cellulase; Bacterial isolates; Rice straw wastes; Sea sands; Biodegradation

Abbreviations: CFU: Colony Forming Units; CMC: Carboxymethyl Cellulose; CMCase: Carboxymethyl Cellulase; DNS: Dinitrosalicylic Acid; MR: Methyl Red; VP: Voges-Proskauer.

\section{Introduction}

Cellulose and hemicelluloses are the most abundant biomasses on the earth and have the greatest potential to resolve both the energetic and environmental demands of bioenergy [1,2]. Cellulose is a linear polysaccharide which consists of 1000-1200 glucose residues with $\beta$-1,4-glycosidic linkages [3]. Cellulases can effectively hydrolyze cellulose into glucose via synergistic action of three enzymes, endo- $\beta$ 1,4-glucanase (EC 3.2.1.4), cellobiohydrolases (EC 3.2.1.91), and $\beta$-Dglucosidase (EC 3.2.1.21) [4,5]. The process is known as cellulolytic system. The endoglucanase randomly hydrolyzes the $\beta-1,4$ bonds in the cellulose molecule, and the exo cellobiohydrolases in most cases release a cellobiose unit showing a recurrent reaction from chain extremity. Finally, the cellobiose is converted to glucose by $\beta$-glucosidase $[6,7]$. Cellulases are inducible enzymes synthesized by a large diversity of microorganisms including both fungi and bacteria during their growth on cellulosic materials. These microorganisms can be aerobic, anaerobic, mesophilic or thermophilic [8,9]. Filamentous fungi are the major source of cellulases and hemicellulases [10] but the production costs of these enzymes are very high. Bacteria which have high growth rate and short generation time in compared to fungi have good potential to be used in cellulase production [11]. The furthermost potential importance is the ease with which bacteria can be genetically engineered. During the last two decades, the use of cellulases, hemicellulases and pectinases has been increased considerably, especially in textile $[12,13]$, food and feed [14], brewery and wine [13] as well as in pulp and paper industries [15-17]. However, the most important use of cellulase is in the bioconversion of plant based cellulosic and lignocellulosic waste, which opens the possibility of virtually inexhaustible and unique source of renewable biofuel $[4,18,19]$. Nowadays, these enzymes account for approximately $20 \%$ of the world enzyme market used on industrial basis [6].

Currently, cellulases are not produced commercially in Bangladesh and tons of cellulases are imported every year to use in different industries. According to Bangladesh Bank, cellulase of 17.8 million US dollar was imported during FY 2011-2012 to bare only in the textile sector, which imposed tremendous demand of cellulase production in Bangladesh. About 7,690 tons of Municipal Solid Wastes (MSW) are produced daily at the six major cities of Bangladesh namely, Dhaka, Chittagong, Rajshahi, Khulna, Barishal and Sylhet which may be increased up to 47,000 tons per day by 2025 owing to increase in population and urbanization. About $75-85 \%$ constituents of the MSW is organic and approximately $80 \%$ of this organic content is cellulosic which can be utilized as raw materials for cellulase production. Currently, MSW in Bangladesh are generally collected and dumped in low lands or disposed haphazardly causing environmental pollution and public health hazards. Methane gas is emitted from the rotten MSW. Methane is the second potent greenhouse gas having 20 times more impact on climate change compared to the carbon dioxide. Therefore, cellulosic

*Corresponding author: Abul Kalam Azad, Department of Genetic Engineering and Biotechnology, Shahjalal University of Science and Technology, Sylhet-3114 Bangladesh, Tel: +880821717850; Fax:+880821725050; E-mail: dakazad-btc@ sust.edu

Received December 12, 2015; Accepted April 25, 2016; Published April 29, 2016

Citation: Khatiwada P, Ahmed J, Sohag MH, Islam K, Azad AK (2016) Isolation Screening and Characterization of Cellulase Producing Bacterial Isolates from Municipal Solid Wastes and Rice Straw Wastes. J Bioprocess Biotech 6: 280 doi:10.4172/2155-9821.1000280

Copyright: (c) 2016 Khatiwada P, et al. This is an open-access article distributed under the terms of the Creative Commons Attribution License, which permits unrestricted use, distribution, and reproduction in any medium, provided the original author and source are credited. 
Citation: Khatiwada P, Ahmed J, Sohag MH, Islam K, Azad AK (2016) Isolation, Screening and Characterization of Cellulase Producing Bacterial Isolates from Municipal Solid Wastes and Rice Straw Wastes. J Bioprocess Biotech 6: 280. doi:10.4172/2155-9821.1000280

biomass of MSW needs to be bioconverted into bioresources through production of value added products such as enzymes. Cellulase can be produced by bacteria using cellulosic MSW as the raw material. With this view, we herein isolated and screened cellulase producing bacterial isolates from MSW and Rice Straw Wastes (RSW) and optimized some parameters for cellulase production. Cellulases produced from these bacterial isolates were partially characterized.

\section{Materials and Methods}

\section{Isolation, screening and identification of cellulase producing bacterial isolates}

Samples were collected from RSW and MSW from different areas of Sylhet district, Bangladesh. One gram of sample was suspended in 9 $\mathrm{ml}$ of sterile distilled water. After serial dilution of this suspension (10 ${ }^{1}$ to $10^{-6}$ times), $200 \mu \mathrm{l}$ of each dilution was spread on carboxymethyl cellulose (CMC) agar plates ( $1 \% \mathrm{CMC}, 0.1 \% \mathrm{KH}_{2} \mathrm{PO}_{4}, 0.1 \% \mathrm{~K}_{2} \mathrm{HPO}_{4}$, $0.04 \% \mathrm{MgSO}_{4}, 0.005 \% \mathrm{NaCl}, 0.000125 \% \mathrm{FeSO}_{4}$ and $1.8 \%$ Agar, $\mathrm{pH}$ 7.0 ) and incubated at $37^{\circ} \mathrm{C}$ for $24-48 \mathrm{~h}$. The isolated bacterial colonies forming clear-zones after application of Gram's iodine solution [20] were selected as cellulase producers. Bacterial isolates producing significant clear zone on CMC agar were identified based on cultural, morphological and biochemical characteristics as described by Cowan and Steel [21].

\section{Crude cellulase production}

A basal media (1\% CMC, $0.1 \% \mathrm{KH}_{2} \mathrm{PO}_{4}, 0.1 \% \mathrm{~K}_{2} \mathrm{HPO}_{4}, 0.04 \%$ $\mathrm{MgSO}_{4}, 0.005 \% \mathrm{NaCl}$, and $0.000125 \% \mathrm{FeSO}_{4}, \mathrm{pH} 7.0$ ) was used for production of cellulase. For seed culture, a fresh isolated colony was inoculated in $5 \mathrm{ml}$ basal media and incubated at $37^{\circ} \mathrm{C}$ and $120 \mathrm{rpm}$ for $24 \mathrm{~h}$. The seed culture (5\%) was then inoculated in $50 \mathrm{ml}$ production media in a $250 \mathrm{ml}$ conical flask and incubated at the conditions as indicated. The cell free supernatant obtained by centrifugation at 8,000 rpm for $15 \mathrm{~min}$ at $4^{\circ} \mathrm{C}$ was used for determining the cellulase activity or further investigations.

\section{Cellulase activity assay}

The carboxy methyl cellulase (CMCase) activity was assayed using a method described by Miller [22], with some modifications [6,23]. A $0.5 \mathrm{ml}$ of culture supernatant was added to $0.5 \mathrm{ml}$ of $1 \%$ CMC prepared in $50 \mathrm{mM}$ sodium citrate buffer ( $\mathrm{pH} 4.8)$ in a test tube and incubated at $60^{\circ} \mathrm{C}$ for 30 $\mathrm{min}$. The reaction was terminated by adding $3.0 \mathrm{ml}$ of dinitrosalicylic acid (DNS) and subsequently placing the reaction tubes in a water bath at $100^{\circ} \mathrm{C}$ for 15 minutes. One $\mathrm{ml}$ of Rochelle salt solution ( $40 \mathrm{gm}$ Rochelle salt in 100 $\mathrm{ml}$ distilled water) was then added to stabilize the color. The absorbance/ Optical Density (OD) was recorded at $575 \mathrm{~nm}$ wave length against a blank of $50 \mathrm{mM}$ sodium citrate buffer. One unit of CMCase activity was defined as the amount of enzyme that liberated $1 \mu \mathrm{mol}$ of reducing sugar (glucose) in $1 \mathrm{~min}$ at $37^{\circ} \mathrm{C}$ and $\mathrm{pH} 7.0$ [24].

\section{Time course study for cellulase production}

To determine the optimum cultivation period for maximum cellulase production, the seed culture was inoculated into the production media and incubated at the conditions as described above. Culture samples were withdrawn at $6 \mathrm{~h}$ interval up to $60 \mathrm{~h}$ of cultivation and the CMCase activity was assayed. Simultaneously, bacterial growth was also observed by counting viable cells in Colony Forming Units (CFU).

\section{Optimization of temperature and $\mathrm{pH}$ for cellulase production}

To study of effects the temperature on cellulase production, production medium at $\mathrm{pH} 7$ was inoculated with the seed culture and incubated at different temperatures $\left(25,30,35,37,40\right.$ and $\left.45^{\circ} \mathrm{C}\right)$. In order to study the effect of $\mathrm{pH}$ on cellulase production, the initial $\mathrm{pH}$ of the production medium was adjusted to different $\mathrm{pH}$ ( $\mathrm{pH} 4.0$ to 9.0). Different suitable buffers such as $50 \mathrm{mM}$ sodium acetate ( $\mathrm{pH} 4.0), 50$ $\mathrm{mM}$ sodium citrate ( $\mathrm{pH} 5.0$ ), $50 \mathrm{mM}$ potassium phosphate ( $\mathrm{pH} 6.0-7.0$ ) and $50 \mathrm{mM}$ Tris-HCl (pH 8.0-9.0) were used. An inoculums size of 5\% was maintained during fermentation at the conditions as indicated [25].

\section{Effects of temperature and $\mathrm{pH}$ on cellulase activity and} stability

To investigate the effects of temperature and $\mathrm{pH}$ on cellulase activity, $500 \mu \mathrm{L}$ of the crude enzyme was added to $500 \mu \mathrm{L}$ of $1 \% \mathrm{CMC}$ in $50 \mathrm{mM}$ citrate buffer ( $\mathrm{pH} 4.8$ ). The reaction mixture was incubated for $30 \mathrm{~min}$ at various temperatures $30,35,40,45,50,55$ and $60^{\circ} \mathrm{C}$. Cellulase activity was then measured as described above. To study the effects of $\mathrm{pH}$ on cellulase activity, different buffers such as $50 \mathrm{mM}$ of sodium citrate ( $\mathrm{pH} 4.0$ and 5.0), potassium phosphate ( $\mathrm{pH}$ 6.0-7.0) and Tris$\mathrm{HCl}(\mathrm{pH} 8.0-9.0)$ were used to assay the CMCase activity. To $0.5 \mathrm{ml}$ of $1 \%$ CMC prepared in a suitable buffer of a particular $\mathrm{pH}(\mathrm{pH} 4-9), 0.5$ $\mathrm{ml}$ of crude enzyme was added.

To investigate the temperature stability, $1 \mathrm{ml}$ of crude enzyme was treated for $1 \mathrm{~h}$ at various temperatures $30,35,40,45,50,55$ and $60^{\circ} \mathrm{C}$. The residual CMCase activity of crude cellulase was measured according to the standard assay procedure. To study the $\mathrm{pH}$ on cellulase stability, the crude cellulase enzyme was treated for $1 \mathrm{~h}$ at room temperature with buffers of different $\mathrm{pH} 4-9$ as described above. Standard assay procedure was followed to measure the residual activity of crude cellulase.

\section{Determination of cellulose degradation capability of the crude cellulase}

A $200 \mathrm{mg}$ filter paper strip was placed in a conical flask containing 50 $\mathrm{ml}$ of crude enzyme (total CMCase activity $~ 2.0 \mathrm{U}$ ) from each bacterial isolate, and incubated in a shaker incubator for 7 days. The amount of glucose liberated from the filter paper was estimated according to the procedure described by Miller [22].

\section{Results and Discussion}

\section{Isolation and screening of cellulase producing bacterial isolates}

Cellulolytic bacteria were isolated from samples collected from RSW and MSW. Appropriate dilutions of each sample were inoculated on CMC agar plates. Using of CMC as the sole carbon source plays a pivotal role for achieving the highest level of cellulase production because CMC induces cellulase gene expression. Isolated bacterial colonies with higher cellulase activity were further screened to obtain the pure culture. The pure culture produced clear zone when it was flooded with Gram's iodine solution due to hydrolysis of CMC (Figure 1). Gram's iodine forms a bluish-black complex with cellulose but not with hydrolyzed cellulose, giving a sharp and distinct clear zone around the cellulase-producing bacterial colonies within 3 to 5 minutes. Clear zone producing bacterial isolates were then subjected to various morphological, cultural and biochemical tests (Table 1). Based on the biochemical tests, morphological and cultural characteristics, isolate MSW3 was identified as Bacillus sp., isolate PA1 was identified as Serratia sp. and isolates RSW3 and PA2 were identified as Pseudomonas spp. In our study, isolate MSW3 was obtained from MSW and isolates PA1, PA2 and RSW3 were from RSW. 
Citation: Khatiwada P, Ahmed J, Sohag MH, Islam K, Azad AK (2016) Isolation, Screening and Characterization of Cellulase Producing Bacterial Isolates from Municipal Solid Wastes and Rice Straw Wastes. J Bioprocess Biotech 6: 280. doi:10.4172/2155-9821.1000280

Page 3 of 5

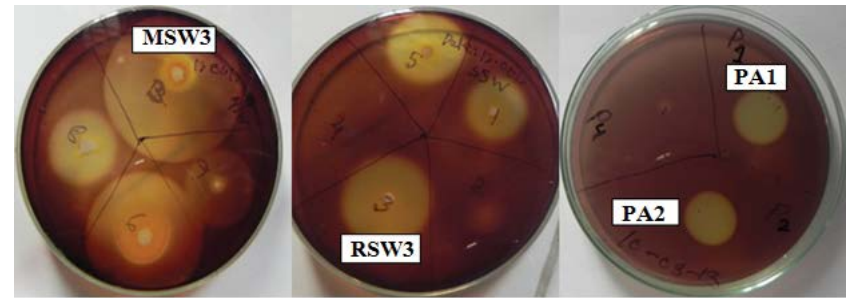

Figure 1: Visualization of cellulase activity with Gram's iodine solution. Cellulolytic bacteria were screened from the master plate to obtain pure culture. Cellulolytic activity was observed on CMC agar media after incubation at $37^{\circ} \mathrm{C}$ for $24 \mathrm{~h}$. Typical results of three independent experiments for cellulolytic bacteria on CMC agar media are shown.

\begin{tabular}{|c|c|c|c|c|}
\hline \multirow{2}{*}{$\begin{array}{c}\text { Morphological and } \\
\text { Biochemical tests }\end{array}$} & \multicolumn{4}{|c|}{ Bacterial isolates } \\
\cline { 2 - 5 } & MSW3 & SSW3 & PA1 & PA2 \\
\hline Bacterial Shape & Rod & Rod & Rod & Irregular \\
\hline Motility Test & Motile & Motile & Motile & Motile \\
\hline Gram Staining & + & - & - & - \\
\hline Catalase Test & + & + & - & - \\
\hline Oxidase Test & $+/-$ & + & + & + \\
\hline Spore Test & - & - & - & - \\
\hline Indole test & - & - & - & - \\
\hline Glucose Fermentation Test & + & + & + & + \\
\hline Lactose Fermentation Test & - & + & $+/-$ & - \\
\hline MR- VP test & & & & + \\
\hline MR & + & + & - & - \\
\hline VP & - & - & - & - \\
\hline Results & $\begin{array}{c}\text { Bacillus } \\
\text { sp. }\end{array}$ & $\begin{array}{c}\text { Pseudomonas } \\
\text { sp. }\end{array}$ & $\begin{array}{c}\text { Serratia } \\
\text { sp. }\end{array}$ & $\begin{array}{c}\text { Pseudomonas } \\
\text { sp. }\end{array}$ \\
\hline
\end{tabular}

Table 1: Biochemical tests for Genus identification of Bacterial isolates.

\section{Fermentation conditions for cellulase production}

Fermentation period, cultivation temperature, initial $\mathrm{pH}$ of the culture media and agitation are the most striking features to influence the production of enzymes [26,27]. Time course study reveals that Bacillus and Serratia isolates (MSW3 and PA1) show maximum cellulase production at $24 \mathrm{~h}$ of cultivation, whereas Pseudomonas isolates (RSW3 and PA2) show optimal cellulase production at $42 \mathrm{~h}$ of cultivation (Figure 2). Along with cellulase production, bacterial cell growth was also observed by counting the colony forming units, the results indicate that cellulase production was growth associated (Figure 2). Cellulolytic bacterial isolates from the Persian Gulf showed their optimal production of cellulase after $48 \mathrm{~h}$ of cultivation [28]. However, optimum cultivation period varies from strain to strain with their characteristics and cultural conditions [29]. Temperature is one of the most important variables controlling bacterial growth and enzyme production.

We optimized temperature for cellulase production. Bacillus and Pseudomonas isolates showed production optima at $37^{\circ} \mathrm{C}$, while Serratia sp. showed maximum cellulase production at $35^{\circ} \mathrm{C}$ (Figure 3 ). However, temperature optima for cellulase production may vary from bacterial species to species $[30,31]$.

The cellulase production by bacterial isolates is controlled by the extracellular $\mathrm{pH}$ as the $\mathrm{pH}$ of the culture media strongly influences many enzymatic processes. We investigated the effects of initial $\mathrm{pH}$ of the media on the production of cellulase by the bacterial isolates. It was observed that the optimum production of cellulase by the all bacterial isolates was observed at initial pH 7 (Figure 4). However, significant levels (approximately $60-70 \%$ of the peak levels) of cellulase production by Pseudomonas sp. were supported by a $\mathrm{pH}$ range between 6.0 and 8.0. This result indicated that the optimum level of cellulase from Pseudomonas isolates was secreted at neutral $\mathrm{pH}$. It was previously reported that cellulolytic bacteria produced highest level of cellulase at a $\mathrm{pH}$ range of 6.0-7.5 [32,33].

\section{Partial characterization of crude cellulase}

It is necessary to optimize the physicochemical conditions for maximum activity of an enzyme before its application. We determined the optimum temperature and $\mathrm{pH}$ for the activity of cellulase produced by the bacterial isolates. Temperature has marked effect on the activities of enzymes [34]. Results showed that the optimum temperature for the cellulolytic activity of cellulase secreted by the bacterial isolates in this study was $40^{\circ} \mathrm{C}$ (Figure 5). Furthermore, effect of temperature on cellulase stability was also studied. The results indicated that crude cellulase was almost stable up to $40-55^{\circ} \mathrm{C}$. However, the stability of

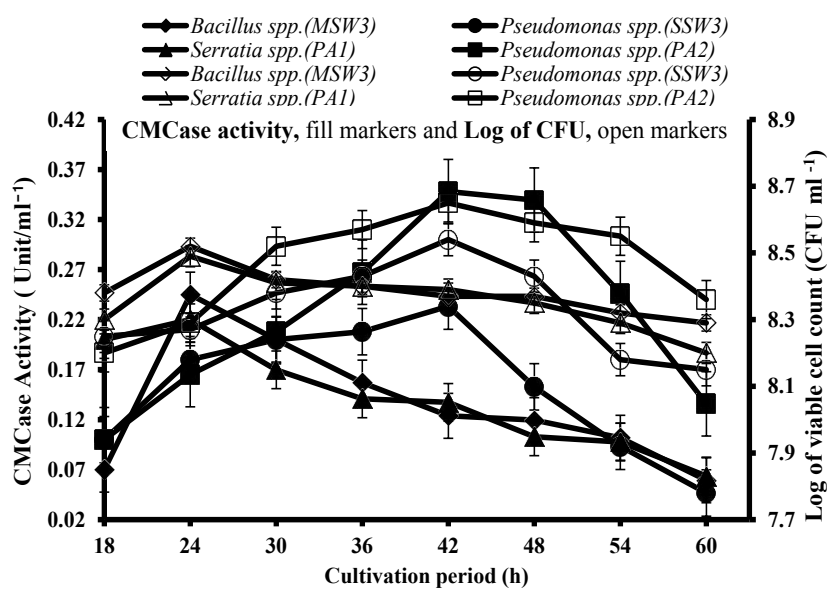

Figure 2: Time course for cellulase production. The fermentation at shake flask was carried out at $37^{\circ} \mathrm{C}$ and $120 \mathrm{rpm}$ with $5 \%$ inoculums size. The initial $\mathrm{pH}$ of the media was adjusted to 7.0. The CMCase activity was determined at 6 $\mathrm{h}$ interval during fermentation. CMCase activity and Viable cell count (Log of CFU) are shown as filled and opened marks, respectively.

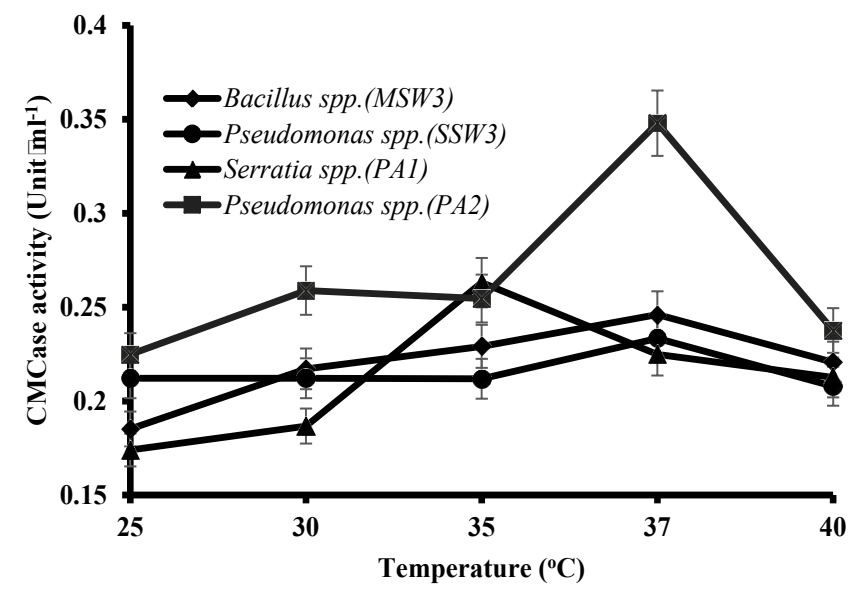

Figure 3: Effects of cultivation temperature on cellulase production Fermentation by Pseudomonas isolates was done at temperature at $25,30,35$ 37 and $40^{\circ} \mathrm{C}$ as indicated at $120 \mathrm{rpm}$ for $42 \mathrm{~h}$ and Bacillus and Serratia isolates was done under the conditions for $24 \mathrm{~h}$. The initial $\mathrm{pH}$ of the culture media was adjusted to 7.0 . 
Citation: Khatiwada P, Ahmed J, Sohag MH, Islam K, Azad AK (2016) Isolation, Screening and Characterization of Cellulase Producing Bacterial Isolates from Municipal Solid Wastes and Rice Straw Wastes. J Bioprocess Biotech 6: 280. doi:10.4172/2155-9821.1000280

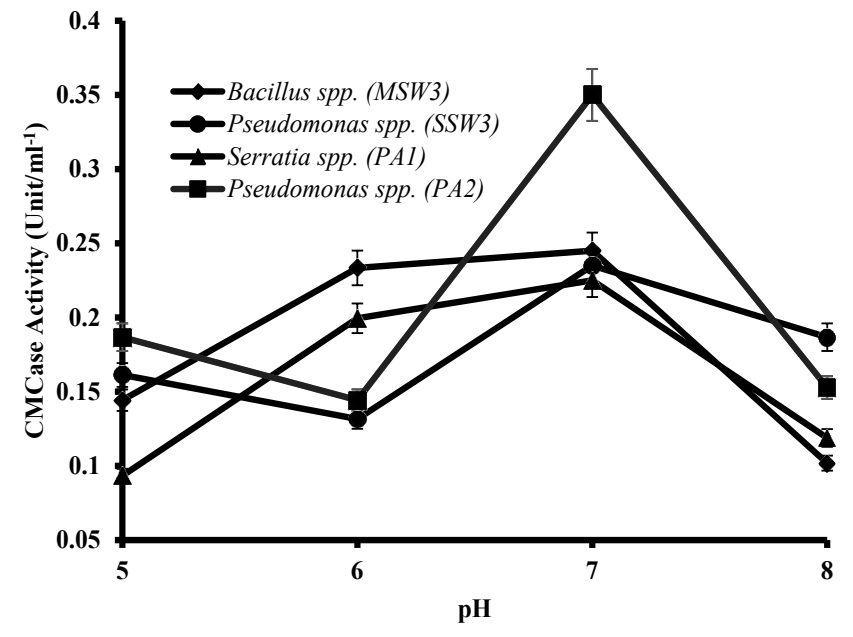

Figure 4: Effects of initial $\mathrm{pH}$ of the media on cellulase production. The initia $\mathrm{pH}$ of the culture media was adjusted to $\mathrm{pH} 4.0,5.0,6.0,7.0,8.0$ and 9.0 . Fermentation by Bacillus, Pseudomonas and Serratia was carried out at $37^{\circ} \mathrm{C}$ and $120 \mathrm{rpm}$ for $42 \mathrm{~h}$ and that by Serratia was done at $35^{\circ} \mathrm{C}$ for $24 \mathrm{~h}$. Cellulase production was optimum at $\mathrm{pH} 7$.

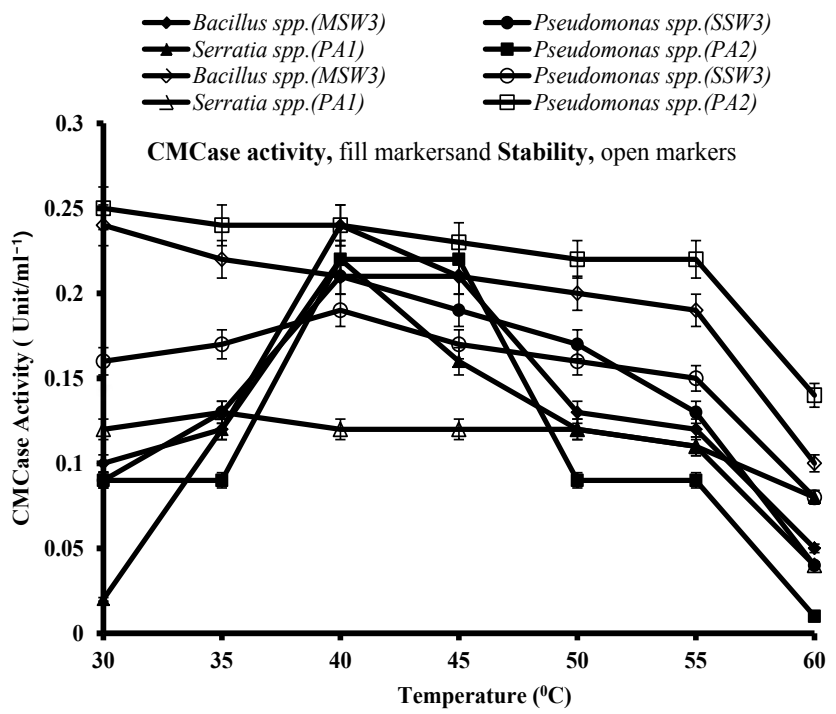

Figure 5: Effects of temperature on cellulase activity. The effects of the temperature on the crude cellulase activity of bacterial isolates were examined at various temperatures ranging from $30^{\circ} \mathrm{C}$ to $60^{\circ} \mathrm{C}$. Cellulase from bacterial isolates show optimum activity at $37^{\circ} \mathrm{C}$, Enzyme activity decreases significantly above $40^{\circ} \mathrm{C}$. CMCase activity at different temperature and temperaturestability shown as fill marker and open markers, respectively.

the crude cellulase decreased sharply when the enzyme solution was treated above $55^{\circ} \mathrm{C}$ (Figure 5).

The effects of $\mathrm{pH}$ on cellulase activity were investigated using $\mathrm{CMC}$ in $50 \mathrm{mM}$ buffer solution with $\mathrm{pH}$ ranging from 4.0-9.0. The maximum cellulase activity was found at $\mathrm{pH} 7$, with activity decreasing significantly both in acidic and neutral $\mathrm{pH}$ (Figure 6). We also examined the $\mathrm{pH}$ stability of the crude cellulase by treating it with buffer solutions of different $\mathrm{pH}$. The cellulase was almost stable for $1 \mathrm{~h}$ at $\mathrm{pH}$ 6.0-8.0. However, cellulase activity was significantly lost when it was treated under $\mathrm{pH} 6.0$ or above $\mathrm{pH} 9.0$ (Figure 6). Although bacterial cellulase can be stable at neutral to alkaline conditions, cellulase from fungal sources are unstable at alkaline condition [35].

\section{Degradation of cellulosic material by crude cellulase}

A $200 \mathrm{mg}$ of filter paper was treated in conical flasks containing $50 \mathrm{ml}$ of crude enzyme. After 3 days of incubation at $37^{\circ} \mathrm{C}$, it was noted by visible inspection that the crude cellulase degraded the filter paper while the filter paper treated with distilled water remained unchanged [36]. Estimation of reducing sugar released in the solution on the $3^{\text {rd }}$ day and $7^{\text {th }}$ day revealed that the filter paper was degraded by crude enzyme (Table 2) [37].

\section{Conclusion}

The present study has isolated four cellulolytic bacteria that have been identified as Bacillus sp., Pseudomonas sp. and Serratia sp. based on morphological, cultural and biochemical characteristics. Different parameters such as fermentation period, cultivation temperature and initial $\mathrm{pH}$ of the culture media during fermentation have been optimized for the production of cellulase by these four bacterial isolates. Moreover, the crude cellulase of these bacterial isolates has been characterized in terms of effects of temperature and $\mathrm{pH}$ on the CMCase activity and stability. In addition, the CMCase activity of the crude enzyme has been characterized based on the capacity of filter paper degradation. Currently, we are performing scale-up of the cellulase production by these bacterial isolates in the bioreactor (Fermac 320, Electrolab, UK) by using cellulosic waste materials of MSW for purification, molecular characterization and application of the cellulase.

\section{Conflict of Interests}

The authors declare that there is no conflict of interests regarding the publication of this paper.

\begin{tabular}{|c|c|c|}
\hline \multirow{2}{*}{$\begin{array}{c}\text { Crude } \\
\text { cellulase of } \\
\text { Isolate }\end{array}$} & Amount of reducing sugar liberated $(\mathrm{mg} / \mathrm{ml})$ at the end \\
\cline { 2 - 3 } & $3^{\text {rd }}$ day & $7^{\text {th }}$ day \\
\hline MSW3 & 10.7 & 18.0 \\
\hline RSW3 & 7.07 & 14.6 \\
\hline PA1 & 5.89 & 11.6 \\
\hline PA2 & 9.54 & 17.5 \\
\hline
\end{tabular}

Table 2: Reducing sugar liberated through degradation of filter paper by crude cellulose.

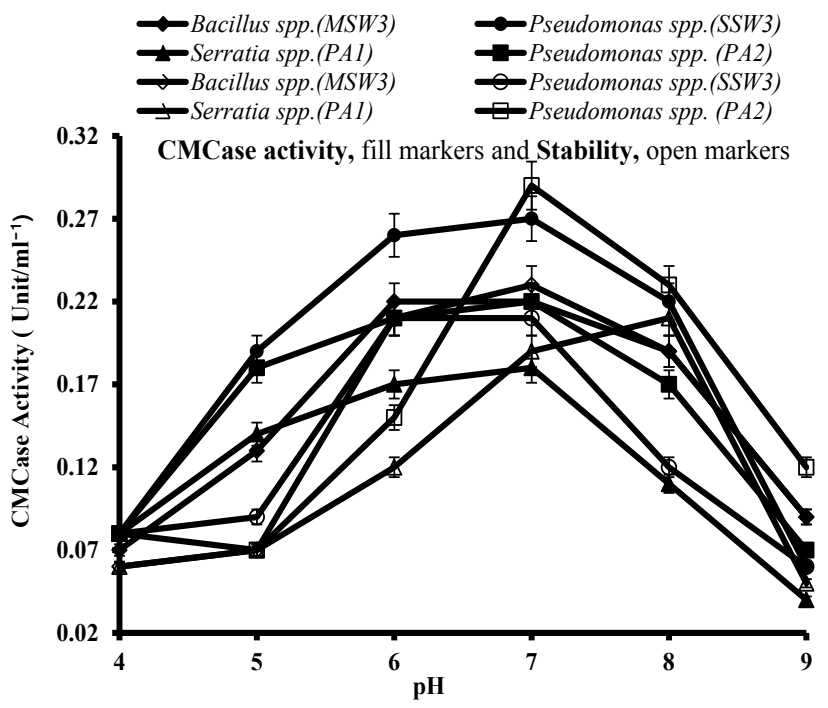

Figure 6: Effects of $\mathrm{pH}$ on cellulase activity. The effects of the $\mathrm{pH}$ on the crude cellulase activity of bacterial isolates were examined at various $\mathrm{pH}$ ranging from $\mathrm{pH} 4.0$ to 9.0. The enzyme has a broad range of $\mathrm{pH}$ activity $(\mathrm{pH} \mathrm{6-8)} \mathrm{with} \mathrm{optimal}$ at $\mathrm{pH}$ 7. CMCase activity at different $\mathrm{pH}$ and $\mathrm{pH}$ stability shown as fill marker and open markers, respectively. 
Citation: Khatiwada P, Ahmed J, Sohag MH, Islam K, Azad AK (2016) Isolation, Screening and Characterization of Cellulase Producing Bacterial Isolates from Municipal Solid Wastes and Rice Straw Wastes. J Bioprocess Biotech 6: 280. doi:10.4172/2155-9821.1000280

Page 5 of 5

\section{Acknowledgements}

JA was supported by a stipend from The World Academy of Sciences for the Advancement of Sciences in Developing Countries (12-150-RG/BIO AS G; UNESCO FR: 12-150-RG/BIO/AS G). The work was supported by a grant-in-aid from the Ministry of Science and Technology, Bangladesh (No. 39.009.006.01.00.042.2012-13/BS-135/518), the World Academy of Sciences (TWAS) (No. 12-150 RG/BIO/AS_G) and research grant from Shahjalal University of Science and Technology, Sylhet-3114, Bangladesh.

\section{References}

1. Sánchez OJ, Cardona CA (2008) Trends in biotechnological production of fue ethanol from different feedstocks. Bioresour Technol 99: 5270-5295.

2. Kim N, Choo YM, Lee KS, Hong SJ, Seol KY, et al. (2008) Molecular cloning and characterization of a glycosyl hydrolase family 9 cellulase distributed throughout the digestive tract of the cricket Teleogryllus emma. Comp Biochem Physiol B Biochem Mol Biol 150: 368-376.

3. Gupta P, Samant K, Sahu A (2012) Isolation of cellulose-degrading bacteria and determination of their cellulolytic potential. Int J Microbiol 2012: 578925.

4. Pérez J, Muñoz-Dorado J, de la Rubia T, Martínez J (2002) Biodegradation and biological treatments of cellulose, hemicellulose and lignin: an overview. Int Microbiol 5: 53-63.

5. Kleman-Leyer KM, Siika-Aho M, Teeri TT, Kirk TK (1996) The Cellulases Endoglucanase I and Cellobiohydrolase II of Trichoderma reesei Act Synergistically To Solubilize Native Cotton Cellulose but Not To Decrease Its Molecular Size. Appl Environ Microbiol 62: 2883-2887.

6. Bhat MK (2000) Cellulases and related enzymes in biotechnology. Biotechno Adv 18: 355-383.

7. Wood TM, Wilson CA, McCrae SI (1994) Synergism between components of the cellulase system of the anaerobic rumen fungus Neocallimastix frontalis and those of the aerobic fungi Penicillium pinophilum and Trichoderma koning in degrading crystalline cellulose. Appl Microbiol Biotechnol 41: 257-261.

8. Kuhad RC, Gupta R, Singh A (2011) Microbial cellulases and their industrial applications. Enzyme Res 2011: 280696

9. Ryu DDY, Mandels M (1980) Cellulases: Biosynthesis and applications. Enzyme and Microbial Technology 2: 91-102.

10. Baldrian P, Valásková V (2008) Degradation of cellulose by basidiomycetous fungi. FEMS Microbiol Rev 32: 501-521.

11. Amore A, Pepe O, Ventorino V, Birolo L, Giangrande C, et al. (2013) Industria waste based compost as a source of novel cellulolytic strains and enzymes. FEMS Microbiol Lett 339: 93-101.

12. Uhlig H (1998) Industrial enzymes and their applications. John Wiley \& Sons, Inc., New York, USA

13. Galante YM, Monterveradi R, Inama S, Caldini C, De Conti A, et al. (1998) New applications of enzymes in wine making and olive oil production. Italian Biochemistry Society Trans 4: 34 .

14. Chesson A (1987) Supplementary enzymes to improve the utilization of pigs and poultry diets. Food and Agriculture Organization, United Nations.

15. Pere J, Paavilainen L, Siikka-Aho M (1996) Potential use of enzymes in drainage control of non-wood pulps. In: 3rd International Non-Wood Fibre Pulping and Paper making Conference 2: 421-430.

16. Akhtar M, Blanchette RA, Kirk TK (2006) Fungal delignification and biomechanical pulping of wood. In: Biotechnology in the Pulp and Pape Industry. Advances in Biochemical Engineering/Biotechnology 57: 159-195.

17. Blanchette RA (1991) Delignification by wood-decay fungi. Annu Rev Phytopathol 29: 381-403.

18. Gautam SP, Bundela PS, Pandey AK, Jamaluddin, Awasthi MK, et al. (2012) Diversity of cellulolytic microbes and the biodegradation of municipal solid waste by a potential strain. Int J Microbiol 2012: 325907.

19. Petre M, Zarnea G, Adrian P, Gheorghiu E (1999) Biodegradation and bioconversion of cellulose wastes using bacterial and fungal cells immobilized in radiopolymerized hydrogels. Resources, Conservation and Recycling 27: 309-332.

20. Kasana RC, Salwan R, Dhar H, Dutt S, Gulati A (2008) A rapid and easy method for the detection of microbial cellulases on agar plates using gram's iodine. Curr Microbiol 57: 503-507.
21. Cowan I, Steel ST (1974) Cowan and Steel's Manual for the identification of medical bacteria. 3rd edn. Cambridge University Press, London.

22. Miller GL (1959) Use of dinitrosalicylic acid reagent for determination of reducing sugar. Anal Chem 31: 426-428.

23. Wood TM, Bhat KM (1988) Methods for measuring cellulase activities. Methods in Enzymology 160: 87-112.

24. Zhang YH, Hong J, Ye X (2009) Cellulase assays. Methods Mol Biol 581: 213 231.

25. Pelczar MJ, Chan ECS, Krieg NR (2004) Microbiology. 5th edn. Tata McGraw Hill, New Delhi, India.

26. Silva-Santisteban BOY, Filho FM (2005) Agitation, aeration and shear stress as key factors in inulinase production by Kluyveromyces marxianus. Enzyme and Microbial Technology 36: 717-724.

27. Domingues FC, Queiroz JA, Cabral JM, Fonseca LP (2000) The influence of culture conditions on mycelial structure and cellulase production by Trichoderma reesei Rut C-30. Enzyme Microb Technol 26: 394-401.

28. Samira M, Mohammad R, Gholamreza G (2011) Carboxymethyl cellulose and filter paperase activity of new strains isolated from Persian Gulf. Microbiology Journal 1: 8-16.

29. Bajaj BK, Pangotra H, Wani MA, Sharma P, Sharma A (2009) Partial purification and characterization of a highly thermostable and $\mathrm{pH}$ stable endoglucanase from a newly isolated Bacillus strain M-9. Indian J Chem Technol 16: 382-387.

30. Immanuel G, Dhanusha R, Prema P, Palavesam A (2006) Effect of different growth parameters on endoglucanase enzyme activity by bacteria isolated from coir retting effluents of estuarine environment. Int J Environ Sci Technol 3: 2534.

31. Rahman Z, Shida Y, Furukawa T, Suzuki Y, Okada H, et al. (2009) Application of Trichoderma reesei cellulase and xylanase promoters through homologous recombination for enhanced production of extracellular beta-glucosidase I. Biosci Biotechnol Biochem 73: 1083-1089.

32. Otajevwo FD, Aluyi HAS (2011) Cultural conditions necessary for optima cellulase yield by cellulolytic bacterial organisms as they relate to residual sugars released in broth medium. Modern Applied Science 5: 141

33. Sozzi GO, Cascone O, Fraschina AA (1996) Effect of a high-temperature stress on endo- $\beta$-mannanase and $\alpha$ - and $\beta$-galactosidase activities during tomato fruit ripening. Postharvest Biol Technol 9: 49-63.

34. Kumari BL, Hanumasri M, Sudhakar P (2011) Isolation of cellulase producing fungi from soil, optimization and molecular characterization of the isolate for maximizing the enzyme yield. World Journal Science Technology 1: 1-9.

35. Alamgir M, Ahsan A (2007) Municipal solid waste and recovery potential: Bangladesh perspective. J Environ Health Sci Eng 4: 67-76.

36. Bahauddin KM, Uddin MH (2012) Prospect of solid waste situation and an approach of Environmental Management Measure (EMM) model fo sustainable solid waste management: Case study of Dhaka city. J Environ Sci \& Natural Resources 5: 99-111.

37. Azad AK, Nahar A, Hasan MM, Islam K, Azim MF, et al. (2013) Fermentation of municipal solid wastes by bacterial isolates for production of raw protein degrading proteases. Asian J Microbiol Biotechnol Environ Sci 15: 365-374. 